of course, but it seems unlikely that this would apply merely to a few tens of metres.

Already the publicists are looking forward to a "Marsokhod" (Pravda, 22 November, 1970) and the advantages of such automatic vehicles in exploring the planets have been emphasized several times. Yet one thing is significant. The instrument unit of the Lunokhod-I preserves ambient conditions which are reminiscent of a life-support system-temperatures of $16^{\circ}-18^{\circ} \mathrm{C}$ and pressures of $730-780 \mathrm{~mm} \mathrm{Hg}$. Although the present emphasis is on automata, the instrumentation of the Lunokhod-1 would not have to be redesigned or adapted in any way if it is later built into the cabin for a manned mission, because it is already designed to operate in such conditions. The constant emphasis, in the Soviet news reports, on the ambient conditions in the instrument compartment may be a hint that plans for a future Soviet manned moon mission have not been shelved.

\section{EUROPEAN SCIENCE}

\section{Makings of a New Structure}

Swemping changes in the way that research and development is controlled inside the European Economic Community have been recommended by the Commission of the EEC. The idea is to replace the present top-heavy decision making machinery by a two tier system consisting of a high level policy making committee and a new European Research and Development Agency (AERD) as its executive arm. The policy committee would consist of officials responsible for research policy in the member countries together with representatives of the most important scientific, economic and social bodies within the EEC. Its function would be to propose to the Commission new forms of community action, either by linking together existing national projects or by the creation of new ventures, and to prepare the ground for the AERD to implement the decisions. 'The AERD would be created under the aegis of the Com. mission but it would control the funds made available to the community for its research and development programme.

The creation of a new body with real, if limited, powers of its own to organize projects on a community basis would take from the shoulders of the commission much of the administrative work which is frequently more a question of organization than of policy. The ultimate policy decisions would still rest, of course, with the Council of Ministers of the six countries but the onus for new proposals and for identifying areas of research ripe for community action would lic with the policy committee, known as the European Research and Development Committee (CERD).

One of the chief architects of the new structure may have been Mr Altiero Spinelli, since last July the member of the Commission with special responsibility for research. In a fiery speech to the European parliament last week, he chided the member states for their failure to take more heed of the call for a common research policy in the EEC. This idea was put forward by the heads of government of the six countries of the EEC when they met in the Hague last year, and Mr Spinelli had some strong words for what he called the "tactic of passive resistance" of the Commission in the past.
A new role is also foreseen for the Joint Research Centre of the EEC, consisting of four research establishments, the largest of which is at Ispra in Italy. The Commission is intending to put forward a transition programme to bring in new fields of research which demand urgent community action. These will include a new programme for research into materials, projects of exploratory research for industry, medical research, meteorology, occanography and, of course, the environment. The conversion of the ESSOR reactor into a fuel-testing light water reactor will be scrapped, but the construction of the SORA pulsed reactor at Ispra will go ahead. The reactor will be thirty times more powerful than the prototype pulsed reactor at Dubna in the Soviet Union and will complement the high flux beam reactor at Grenoble for research into the physics of condensed media and in chemistry.

The Commission points out that the list of areas of research calling for urgent action by the EEC is a long one, and it points out that the reorganization of the Joint Research Centre will be reviewed and expanded as soon as the CERD has found its feet in the new structure.

\section{NUCLEAR ENERGY Consolidation in ENEA}

Although the latest Annual Report of the European Nuclear Energy Agency (Organization for Economic Cooperation and Development, Paris; 1970) describes the past year as "more one for consolidation of existing efforts than one marked by innovation" it was, nevertheless, marked by the first implantation of a radioisotope powered cardiac pacemaker in Paris last April and by the extension of the research programme centred on the Norwegian Boiling Heavy Water Reactor at Halden in Norway.

The extension of the Halden agreement means that the two principal reactor projects run by the agency (the other being the Dragon High Temperature Reactor project located at the UK Atomic Energy Authority establishment at Winfrith, Dorset) will both continue well into the 1970s. At Halden, where $25 \mathrm{MW}$ of heat is extracted but no electricity generated, the chief features of the research will still be irradiation tests of experimental fuels and studies of the problems encountered in the computer control of reactors. An integral part of this work is the development of in-core instruments such as pressure transducers to monitor fuel and distortions in the can.

The troubles at the Dragon reactor in 1968, caused by the corrosion of the primary heat exchangers in which helium gas circulates, were substantially reduced by a change in the method of treating the secondary circuit water. At the end of 1969, however, other heat exchanger failures occurred during a shutdown and the opportunity was taken to replace the heat exchangers with new units which were, in any case, to have been inserted in early 1970. In spite of these setbacks at Dragon, where the reactor technology research is undertaken with the collaboration of several European firms, there are confident predictions in the report that the first commercial high temperature reactor will be commissioned by 1975 .

The cardiac pacemaker resulted from development work carried out by the French Commissariat à 